\title{
Estrone and $17 \beta$-estradiol concentrations in pasteurized-homogenized milk and commercial dairy products
}

\author{
D. A. Pape-Zambito, ${ }^{*}$ R. F. Roberts, $\nmid$ and R. S. Kensinger ${ }^{* 1}$ \\ *Department of Dairy and Animal Science, and \\ †Department of Food Science, The Pennsylvania State University, University Park 16802
}

\begin{abstract}
Some individuals fear that estrogens in dairy products may stimulate growth of estrogen-sensitive cancers in humans. The presence of estrone $\left(\mathrm{E}_{1}\right)$ and $17 \beta$-estradiol $\left(\mathrm{E}_{2}\right)$ in raw whole cow's milk has been demonstrated. The objectives of this study were to determine if pasteurization-homogenization affects $\mathrm{E}_{2}$ concentration in milk and to quantify $\mathrm{E}_{1}$ and $\mathrm{E}_{2}$ concentrations in commercially available dairy products. The effects of pasteurization-homogenization were tested by collecting fresh raw milk, followed by pasteurization and homogenization at 1 of 2 homogenization pressures. All treated milks were tested for milk fat globule size, percentages of milk fat and solids, and $\mathrm{E}_{2}$ concentrations. Estrone and $\mathrm{E}_{2}$ were quantified from organic or conventional skim, $1 \%, 2 \%$, and whole milks, as well as half-andhalf, cream, and butter samples. Estrone and $\mathrm{E}_{2}$ were quantified by RIA after organic solvent extractions and chromatography. Pasteurization-homogenization reduced fat globule size, but did not significantly affect $\mathrm{E}_{2}$, milk fat, or milk solids concentrations. Estrone concentrations averaged $2.9,4.2,5.7,7.9,20.4,54.1 \mathrm{pg} /$ $\mathrm{mL}$, and $118.9 \mathrm{pg} / \mathrm{g}$ in skim, $1 \%, 2 \%$, and whole milks, half-and-half, cream, and butter samples, respectively. $17 \beta$-Estradiol concentrations averaged $0.4,0.6,0.9$, $1.1,1.9,6.0 \mathrm{pg} / \mathrm{mL}$, and $15.8 \mathrm{pg} / \mathrm{g}$ in skim, $1 \%, 2 \%$, whole milks, half-and-half, cream, and butter samples, respectively. The amount of fat in milk significantly affected $\mathrm{E}_{1}$ and $\mathrm{E}_{2}$ concentrations in milk. Organic and conventional dairy products did not have substantially different concentrations of $\mathrm{E}_{1}$ and $\mathrm{E}_{2}$. Compared with information cited in the literature, concentrations of $\mathrm{E}_{1}$ and $\mathrm{E}_{2}$ in bovine milk are small relative to endogenous production rates of $\mathrm{E}_{1}$ and $\mathrm{E}_{2}$ in humans.
\end{abstract}

Key words: estrone, $17 \beta$ estradiol, pasteurizationhomogenization, commercial milk

Received November 25, 2009.

Accepted February 23, 2010.

${ }^{1}$ Corresponding author: ron.kensinger@okstate.edu

\section{INTRODUCTION}

In 2009, more than 255,000 American women were estimated to be diagnosed with new cases of breast, uterine, or ovarian cancers, accounting for $35 \%$ of newly diagnosed cancers in women (Jemal et al., 2009). Estrogens, including $17 \beta$-estradiol $\left(\mathbf{E}_{2}\right)$, estriol, estrone $\left(\mathbf{E}_{1}\right)$, and $17 \alpha$-estradiol, listed in order of potency (Tollefsen et al., 2003), are steroid hormones that regulate reproduction in males and females, but also have associations with the aforementioned cancers. Estrogens act through classic nuclear receptor-mediated pathways and nonclassical pathways to modify protein synthesis and signal transduction pathways, respectively. After estrogens elicit their effects, they are primarily converted into water-soluble forms, such as estrone sulfate, by hepatic phase I and II conjugation enzymes. These water-soluble metabolites are substantially less potent than the original compounds. Although estrogens are naturally produced hormones, high serum estrogen concentrations have been associated with increased risks for breast, uterine, and ovarian cancers (Yue et al., 2003). The public recognizes that consumption of foods with estrogen or estrogen-like substances could be considered a route of exposure to estrogens, potentially leading to increased serum estrogen concentrations. Although milk is a valuable nutrient source, recent reports have questioned the safety of milk because of steroid hormones, including estrogens (Li et al., 2003; Qin et al., 2004; Ganmaa and Sato, 2005). Dairy products have been estimated to account for up to $60 \%$ of estrogens in a German diet (Hartmann et al., 1998). Some authors have proposed that estrogens in milk may be responsible for increased cancer risk (Li et al., 2003; Qin et al., 2004; Ganmaa and Sato, 2005), male reproductive disorders (Sharpe and Skakkebaek, 1993, Ganmaa et al., 2001), and adolescent weight gain (Berkey et al., 2005). Unfortunately, few researchers have reported the concentrations of estrogens in milk, and even less is known about the concentration of estrogens in milk with different amounts of fat. Because of the solubility of estrogens in fat, greater quantities of estrogen would be expected in dairy products with more fat, but this 
is yet to be shown in a large-scale study. Wolford and Argoudelis (1979) reported that raw milk $(\mathrm{n}=2)$ contained $55.8 \mathrm{pg}$ of $\mathrm{E}_{1} / \mathrm{mL}$ and $12.3 \mathrm{pg}$ of $\mathrm{E}_{2} / \mathrm{mL}$, whereas commercial whole milk ( $\mathrm{n}=2$ to 4 ) had $33.7 \mathrm{pg}$ of $\mathrm{E}_{1} /$ $\mathrm{mL}$ and $6.4 \mathrm{pg}$ of $\mathrm{E}_{2} / \mathrm{mL}$. Others (Hartmann et al., 1998) reported total (free + conjugated) $\mathrm{E}_{1}$ content of $130,260,1,470,160$, and $170 \mathrm{pg} / \mathrm{g}$ for milk (3.5\% fat), cream, butter, yogurt, and Gouda cheese, respectively. Total $\mathrm{E}_{2}$ concentrations were $<30 \mathrm{pg} / \mathrm{g}$ in Gouda cheese, butter, and cream, and $<20 \mathrm{pg} / \mathrm{g}$ in milk ( $3.5 \%$ fat) and yogurt. It seems, however, that only 1 to 2 samples per product were used to quantify estrogens (Hartmann et al., 1998). Estrone averaged 1,700, 1,400, and 1,400 $\mathrm{pg} / \mathrm{mL}$ in skim milk (0.3\% fat), half-skim milk $(1.6 \%$ fat), and whole milk ( $4 \%$ fat) $(\mathrm{n}=5 /$ product $)$, respectively (Garcia-Peláez et al., 2004). Others analyzed $\mathrm{E}_{1}, 17 \alpha$-estradiol, $\mathrm{E}_{2}$, and estriol in commercial milks (Malekinejad et al., 2006). 17 $\alpha$-Estradiol and estriol concentrations were below the limit of detection of their assay, whereas free $\mathrm{E}_{1}$ averaged 20.0,17.1, and $8.2 \mathrm{pg} /$ $\mathrm{mL}$ and free $\mathrm{E}_{2}$ averaged 20.6, 13.9, and $10.3 \mathrm{pg} / \mathrm{mL}$ for milks with $3.5,1.5$, and $0 \%$ fat, respectively (Malekinejad et al., 2006). In a similar study, concentrations of total $\mathrm{E}_{1}, 17 \alpha-\mathrm{E}_{2}$, and $17 \beta-\mathrm{E}_{2}$ were $152.8,39.4$, and 23.0 $\mathrm{pg} / \mathrm{mL}$ when 12 whole, half-skimmed, and skim milks were combined (Courant et al., 2007). Subsequently, this group reported free concentrations of $14.1,7.2$, and $6.0 \mathrm{pg}$ of $\mathrm{E}_{1} / \mathrm{mL}$ and $3.0,2.6$, and $1.5 \mathrm{pg}$ of $17 \beta \mathrm{E}_{2} / \mathrm{mL}$ in whole, half-skimmed, and skimmed $(\mathrm{n}=8 \mathrm{each})$ milk samples (Courant et al., 2008). Variation in absolute quantities of $\mathrm{E}_{1}, 17 \alpha-\mathrm{E}_{2}$, and $17 \beta-\mathrm{E}_{2}$ reported in these studies is likely because of different analytical methods (i.e., RIA and GC-MS). These studies had value but the number of samples used for analyses was low $(\mathrm{n} \leq$ 8). More recently, however, $\mathrm{E}_{2}$ concentrations were analyzed from 334 commercial milk samples (Vicini et al., 2008). Concentrations of $\mathrm{E}_{2}$ averaged 4.97 and $6.40 \mathrm{pg} /$ $\mathrm{mL}$ in conventional (no organic or bST-free label) and organic whole milks, respectively. Data for other milks (skim, 2\%) and additional dairy products (cream or butter) were not presented. Therefore, it is important to quantify estrogens from a larger number of dairy products with different amounts of fat and compare them to physiologically relevant levels in humans as a first step in evaluating potential adverse human health consequences attributed to consuming dairy products.

Objective 1 was to determine if pasteurizationhomogenization $(\mathbf{P}-\mathbf{H})$ treatment affects $\mathrm{E}_{2}$ concentrations in whole cows' milk by comparing $\mathrm{E}_{2}$ concentrations in raw milk with those in the same raw milk that underwent a pasteurization-homogenization treatment. Objective 2 was to quantify $\mathrm{E}_{1}$ and $\mathrm{E}_{2}$ in $>50$ commercially available dairy products of conventional and organic origin to determine the amount of $\mathrm{E}_{1}$ and $\mathrm{E}_{2}$ consumers would be exposed to when consuming dairy products.

\section{MATERIALS AND METHODS}

\section{P-H Study Sample Collection-Experiment 1}

For objective 1, a study was designed to test whether or not $\mathrm{P}-\mathrm{H}$ treatment affected $\mathrm{E}_{2}$ concentrations in milk. Fresh raw milk $(100 \mathrm{~kg})$ was collected from the Pennsylvania State University bulk tank on each of 4 consecutive days. Milk (1 L) was thoroughly mixed, subsampled, and subjected to no further treatment, and was designated as the raw sample. The remaining milk was then pasteurized at $79.4^{\circ} \mathrm{C}$ for 16 to $18 \mathrm{~s}$, and then homogenized at either $6.89 \mathrm{MPa}$ (first stage) and $3.45 \mathrm{MPa}$ (second stage), which was designated low, for low pressure homogenization, or $17.23 \mathrm{MPa}$ (first stage) and $3.45 \mathrm{MPa}$ (second stage), which was designated as high, for high pressure homogenization. Both of these homogenization pressure settings are representative of homogenization pressures used in the dairy processing industry. Incidentally, increased homogenization pressures will lead to decreased milk fat globule sizes. Milk fat and solids were analyzed using a Smart Trac analyzer (CEM Corporation, Matthews, NC). Fat globule size was analyzed using a laser diffraction analyzer (Horiba Instruments, Irvine, CA). Milk fat globule size and percentages of milk fat and solids were analyzed immediately after P-H treatments, whereas the remaining milk samples were stored at $-20^{\circ} \mathrm{C}$ until analyzed for $\mathrm{E}_{2}$.

\section{Commercial Dairy Products Study Sample Collection-Experiment 2}

Commercial milks with various amounts of fat [skim $(<0.05 \%), 1 \%$ fat, $2 \%$ fat, and whole (minimum $3.25 \%$ fat)] were purchased from grocery stores in the State College, Pittsburgh, and Philadelphia regions of Pennsylvania. All samples were placed on ice and transported to the laboratory. Seven unique brands of milk labeled certified organic and 11 unique brands of conventional milk (no organic or recombinant bST-free label) at each fat percentage were purchased. All brands were represented at each fat percentage with the exception of one organic milk brand, for which only skim, $2 \%$, and whole milk were available ( $\mathrm{n}=71$ total samples). Seventeen different milk-processing plants were represented among the 71 samples. Half-and-half $(\mathrm{n}=9 ; 1$ organic), cream ( $\mathrm{n}=6 ; 0$ organic), and butter $(\mathrm{n}=$ $12 ; 4$ organic) were also purchased for analyses of $\mathrm{E}_{1}$ and $\mathrm{E}_{2}$. Milk and butter samples were frozen at $-20^{\circ} \mathrm{C}$ before analyses of $\mathrm{E}_{1}$ and $\mathrm{E}_{2}$. Freezing half-and-half and 


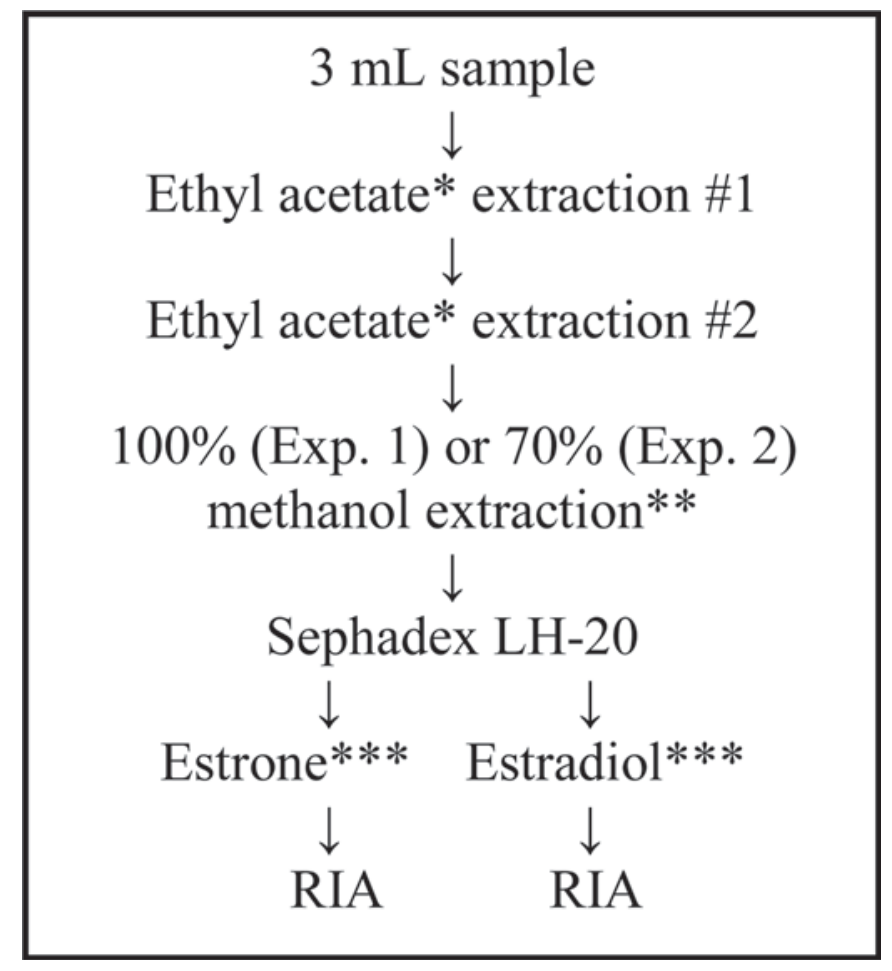

Figure 1. Diagram illustrating extraction of estrone $\left(\mathrm{E}_{1}\right)$ and $17 \beta$-estradiol $\left(\mathrm{E}_{2}\right)$ from pasteurized-homogenized (P-H) milk and commercial dairy products. ${ }^{*}$ Ethyl acetate extractions followed by $100 \%$ methanol extraction procedures were used for the P-H study described in experiment 1 , whereas ethyl acetate:hexane $(1: 1, \mathrm{vol} / \mathrm{vol})$ extractions were used for experiment 2 in which commercial dairy products were analyzed. ${ }^{* *}$ Commercial cream and butter samples required an additional $50 \%$ methanol extraction to remove residual triglycerides and other interfering lipophilic substances before Sephadex LH-20 column (GE Healthcare, Piscataway, NJ) chromatography. ***Each sample was reconstituted in $125 \mu \mathrm{L}$ of castrated male lamb plasma and a minimum of 2 replicates $(50 \mu \mathrm{L}$ each) were run in the respective RIA.

cream is not recommended because the texture of the products is affected upon thawing. As such, half-andhalf and cream samples were refrigerated at $4^{\circ} \mathrm{C}$ for up to $4 \mathrm{~d}$ after purchase before being analyzed for $\mathrm{E}_{1}$ and $\mathrm{E}_{2}$.

\section{Extraction and Isolation of Estrone and 17 $\beta$-Estradiol from Milk}

Solvent extraction procedures were adapted from Monk et al. (1975) and Wolford and Argoudelis (1979) and are similar to methods reported by Pape-Zambito et al. $(2007,2008)$. Figure 1 provides a diagram of the extraction and analysis. Homogenized milk samples were thawed in a warm water bath $\left(37^{\circ} \mathrm{C}\right)$ and vortexed for $10 \mathrm{~s}$ before aliquoting $3.0 \mathrm{~mL}$ into each of four 50 $\mathrm{mL}$, screw-cap glass extraction tubes. Duplicate subsamples were used for half-and-half and cream samples. Butter samples $(0.65 \mathrm{~g})$ were weighed and warmed to $37^{\circ} \mathrm{C}$ for $30 \mathrm{~min}$ before extraction. Milk samples from experiment 1 were each extracted with $9 \mathrm{~mL}$ of ethyl acetate (cat. no. JT9280-33, J T Baker, Phillipsburg, NJ). Ethyl acetate:hexanes (9 mL, 1:1 vol/vol, hexanesACS grade, cat. no. 293253; Sigma-Aldrich, St. Louis, MO) were used for the initial extraction of commercial milk, half-and-half, cream, and butter samples, in contrast to ethyl acetate alone, because that combination yielded greater extraction efficiencies (Figure 1). The mixture of milk + solvent was vortexed for $30 \mathrm{~s}$ and then placed on an orbital shaker for 15 min. Vortex and shaking steps were repeated before incubation at $-20^{\circ} \mathrm{C}$ for $2 \mathrm{~h}$. The resultant liquid organic layer was transferred to a glass test tube and dried under $\mathrm{N}_{2}$ at $55^{\circ} \mathrm{C}$. The ethyl acetate:hexane extraction was then repeated. After freezing, the organic layer from the second extraction was transferred to a corresponding sample tube and dried again. Warm $\left(55^{\circ} \mathrm{C}\right)$ methanol [2 mL of 100\% methanol for experiment 1 (cat. no. BJAH230-4, Burdick and Jackson, Muskegon, MI); 2 $\mathrm{mL}$ of $70 \%$ methanol in Milli-Q water for experiment 2] was added to the extract. The mixture was incubated at $55^{\circ} \mathrm{C}$ for $1 \mathrm{~h}$ with thorough mixing at $0,15,30,45$, and $60 \mathrm{~min}$. The mixture was subsequently incubated at $-20^{\circ} \mathrm{C}$ for $1 \mathrm{~h}$ and then centrifuged at $1,370 \times g$ for 30 min at $4^{\circ} \mathrm{C}$ to precipitate triglycerides and most of the cholesterol. Supernatant solutions from the quadruplicate subsamples were pooled in a clean test tube to increase the mass of $\mathrm{E}_{1}$ and $\mathrm{E}_{2}$ in the RIA tubes. The supernatant solution containing the steroid hormone fraction was dried under $\mathrm{N}_{2}$ at $55^{\circ} \mathrm{C}$.

The estrogen-containing extract was reconstituted in $0.1 \mathrm{~mL}$ of benzene:methanol (9:1, vol/vol; benzene cat. no. 319953, Sigma-Aldrich). Column chromatography was used to separate $\mathrm{E}_{1}$ and $\mathrm{E}_{2}$ from residual cholesterol and other steroids (Mikhail et al., 1970). Sephadex LH20 (cat. no. 17-0090-10, GE Healthcare, Piscataway, $\mathrm{NJ}$ ) was packed to a height of $2.5 \mathrm{~cm}$ in glass columns with an internal diameter of $1 \mathrm{~cm}$. Steroids were eluted with benzene:methanol $(9: 1, \mathrm{vol} / \mathrm{vol})$ as described by Kensinger et al. (1986) and Pape-Zambito et al. (2007, 2008). The $17 \beta$-estradiol elution pattern was verified with $2,4,6,7-{ }^{3} \mathrm{H}-\mathrm{E}_{2}$ (cat. no. TRK322, GE Healthcare), and the $\mathrm{E}_{1}$ elution pattern was verified using $2,4,6,7-{ }^{3} \mathrm{H}$ $\mathrm{E}_{1}$ (cat. no. TRK321, GE Healthcare). In addition, we have confirmed the removal of cholesterol in the $\mathrm{E}_{2}$ fraction when this methodology is used. $17 \beta$-Estradiol fractions were dried under $\mathrm{N}_{2}$ at $55^{\circ} \mathrm{C}$.

\section{Quantification of Estrone and $17 \beta$-Estradiol by RIA}

The dried $\mathrm{E}_{2}$ fraction from each milk sample was reconstituted in $125 \mu \mathrm{L}$ of castrated male lamb plasma before quantification using an RIA specific for $\mathrm{E}_{2}$ (cat. 
no. 07-138106, MP Biomedicals, Irvine, CA). Samples were run in duplicate according to manufacturer instructions. Samples or standards $(50 \mu \mathrm{L})$ were added with the anti- $\mathrm{E}_{2}$ antibody and ${ }^{125}$ I-labeled $\mathrm{E}_{2}$ and incubated at $37^{\circ} \mathrm{C}$ for $90 \mathrm{~min}$. Secondary antibody was then added, thoroughly mixed, and centrifuged at 1,000 $\times g$ for $20 \mathrm{~min}$ at $4^{\circ} \mathrm{C}$. Supernatant solutions were aspirated and the pellets counted on a gamma counter (RIA WizCalc, Perkin Elmer, Waltham, MA).

Dried $\mathrm{E}_{1}$ fractions from experiment 2 were reconstituted in $125 \mu \mathrm{L}$ of castrated male lamb plasma before quantification using an RIA specific for $\mathrm{E}_{1}$ (cat. no. DSL-8700, Diagnostic Systems Laboratory, Webster, TX) similar to that described for $\mathrm{E}_{2}$.

Tritiated $\mathrm{E}_{1}$ and $\mathrm{E}_{2}$ were used as internal standards with each set of samples extracted to quantify percentage $\mathrm{E}_{1}$ and $\mathrm{E}_{2}$ recovery from all sample types analyzed. Tritiated $\mathrm{E}_{1}$ or $\mathrm{E}_{2}(0.01 \mu \mathrm{Ci})$ was added to pooled samples before any extraction step. After the final reconstitution step in castrated male lamb plasma, the internal standards $(125 \mu \mathrm{L})$ were pipetted into 7 -mL scintillation vials with $5 \mathrm{~mL}$ of Ecolite scintillation fluid (ICN, Costa Mesa, CA) and counted with a Beckman LS 6500 scintillation counter (Beckman Coulter, Fullerton, CA). Preliminary studies evaluated parallelism, recovery of a standard mass of $\mathrm{E}_{1}$ and $\mathrm{E}_{2}$ added to samples, as well as recoveries of ${ }^{3} \mathrm{H}-\mathrm{E}_{1}$ and ${ }^{3} \mathrm{H}-\mathrm{E}_{2}$ added to milk samples (Pape-Zambito et al., 2007, 2008).

\section{Statistical Analyses-Experiment 1}

All samples were corrected for recovery of ${ }^{3} \mathrm{H}-\mathrm{E}_{2}$ from milk. The quantity of $\mathrm{E}_{2}$ was related back to the volume of milk extracted. The SAS software (version 8.2; SAS Inst. Inc., Cary, NC) was used for all statistical analyses. A generalized linear model (procedure GLM; SAS Inst. Inc.) was used to determine the effect of $\mathrm{P}-\mathrm{H}$ treatment. Dependent variables included $\mathrm{E}_{2}$ concentration, milk fat, and milk solids, whereas the $\mathrm{P}-\mathrm{H}$ treatment was the independent variable. Orthogonal contrasts were used to compare the $\mathrm{P}-\mathrm{H}$ treatments on $\mathrm{E}_{2}$ concentration, percentages of milk fat and solids, and fat globule size. Contrasts were raw versus low and high $\mathrm{P}-\mathrm{H}$ treatments, and low versus high $\mathrm{P}-\mathrm{H}$ treatments. Simple correlations among variables of interest were calculated (procedure CORR; SAS Inst., Inc.) to determine relationships among $\mathrm{E}_{2}$, milk fat, and milk solids. Differences were considered significant at $P<$ 0.05 .

\section{Statistical Analyses-Experiment 2}

Reported $\mathrm{E}_{1}$ and $\mathrm{E}_{2}$ concentrations were corrected for recoveries of ${ }^{3} \mathrm{H}-\mathrm{E}_{1}$ and ${ }^{3} \mathrm{H}-\mathrm{E}_{2}$, respectively. All data were adjusted to the volume of sample initially extracted. Concentrations of $\mathrm{E}_{1}$ and $\mathrm{E}_{2}$ in butter are reported as picograms per gram and were calculated using the initial weight of butter extracted for analyses.

The SAS software (version 9.1) was used for statistical analyses. For milk samples, a generalized linear model (procedure GLM) was used to test the effects of $E_{1}$ or $E_{2}$ on the type of product (conventional or organic), milk fat percentage, and the interaction between type of product and milk fat percentage. Dependent variables included $E_{1}$ and $E_{2}$ concentrations, whereas the independent variables included milk type, milk fat, and the interaction between type of product and milk fat percentage (type $\times$ fat). Differences in least squares means for $\mathrm{E}_{1}$ and $\mathrm{E}_{2}$ concentrations in different milk product samples were determined by ANOVA and compared among samples by least squares differences. Differences were considered significant at $P<0.05$.

\section{RESULTS}

\section{Experiment 1}

Fat globule size averaged $4.58 \mu \mathrm{m}$ in the raw samples and only 0.59 and $0.39 \mu \mathrm{m}$ in the low and high $\mathrm{P}-\mathrm{H}$ treatments, respectively. Recoveries of tritiated $\mathrm{E}_{2}$ standards averaged $69.5,35.3$, and $34.2 \%$ for raw, low, and high P-H treatments, respectively. 17 $\beta$-Estradiol concentrations averaged $0.70,0.58$, and $0.64 \mathrm{pg} / \mathrm{mL}$ for raw, low, and high $\mathrm{P}-\mathrm{H}$ treatments, respectively, and did not vary $(P>0.35)$ among treatments. Percentages of milk fat averaged $3.59,3.55$, and $3.55 \%$ for raw, low, and high P-H treatments, respectively, and did not vary $(P>0.60)$ among treatments. Percentages of milk solids averaged $12.43,12.41$, and $12.47 \%$ for raw, low, and high P-H treatments, respectively, and did not vary $(P>0.40)$ among treatments. $17 \beta$-Estradiol was positively $(\mathrm{r}=0.58, P<0.05)$ correlated with percentage milk fat.

\section{Experiment 2}

Recoveries of ${ }^{3} \mathrm{H}-\mathrm{E}_{1}$ averaged 91 to $94 \%$ in milks, but only 37 to $72 \%$ in products with more fat (such as butter). Likewise, recovery of ${ }^{3} \mathrm{H}-\mathrm{E}_{2}$ averaged 62 to $68 \%$ in milks and 44 to $57 \%$ in products with more fat. Pooling of milk samples (4 subsamples $\times 3 \mathrm{~mL}$ as indicated in the Methods section) was performed so that $\mathrm{E}_{1}$ and $\mathrm{E}_{2}$ were detected in $100 \%$ of the samples analyzed. Preliminary experimentation analyzing smaller volumes of milk reduced the percentage of quantifiable samples. Greater $(P<0.001)$ concentrations of $\mathrm{E}_{1}$ were found in milk samples as fat percentage increased (Figure 2). Type of milk (conventional vs. organic) did not affect $(P>0.4)$ 


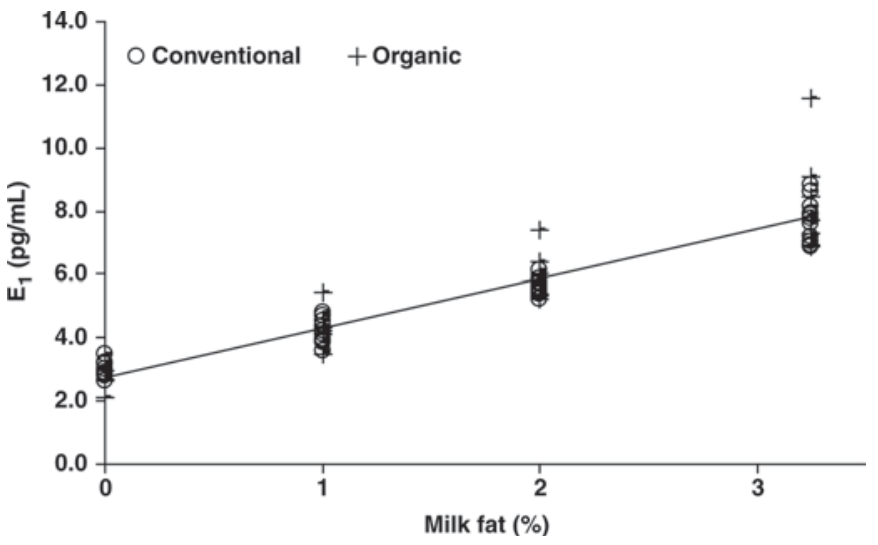

Figure 2. Estrone $\left(\mathrm{E}_{1}\right)$ concentrations in commercial milk samples. Estrone was quantified in conventional and organic skim ( $<0.05 \%$ fat $)$, $1 \%$ fat, $2 \%$ fat, and whole (minimum $3.25 \%$ fat) milk samples. Eleven different conventional brands $(\bigcirc)$ and 7 different brands of organic milk $(+)$ are represented at each milk fat level. The regression line that describes the data for both the conventional and organic milk samples is $\mathrm{y}=1.55 \mathrm{x}+2.75(\mathrm{r}=0.94)$.

$\mathrm{E}_{1}$ concentrations in milk. Concentrations averaged 3.0, $4.2,5.7$, and $7.7 \pm 0.21 \mathrm{pg} / \mathrm{mL}$ in conventional samples with increasing amounts of fat, respectively, and 2.6, $4.3,5.9$, and $8.3 \pm 0.26 \mathrm{pg} / \mathrm{mL}$ in organic samples with increasing amounts of fat, respectively.

Concentrations of $\mathrm{E}_{2}$ increased $(P<0.001)$ as milk fat percentage increased (Figure 3 ). 17 $\beta$-Estradiol concentrations averaged $0.4,0.6,0.8$, and $1.1 \pm 0.05 \mathrm{pg} /$ $\mathrm{mL}$ in conventional milks with increasing amounts of fat, respectively, and $0.4,0.6,1.2$, and $1.2 \pm 0.07 \mathrm{pg} /$

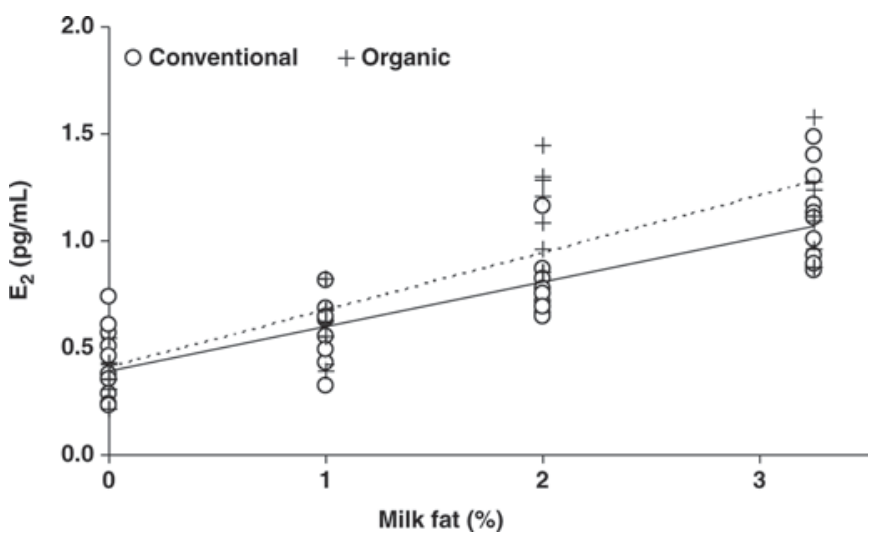

Figure 3. 17 $\beta$-Estradiol $\left(\mathrm{E}_{2}\right)$ concentrations in commercial milk samples. $17 \beta$-Estradiol was quantified in conventional and organic skim ( $<0.05 \%$ fat), $1 \%$ fat, $2 \%$ fat, and whole (minimum $3.25 \%$ fat) milk samples. Eleven different conventional brands $(\bigcirc)$ and 7 different brands of organic milk $(+)$ are represented at each milk fat level. The solid regression line, which describes the data for the conventional milk samples, is $\mathrm{y}=0.21 \mathrm{x}+0.40(\mathrm{r}=0.83)$. The dotted regression line, which describes the data for organic milk samples, is $\mathrm{y}=0.27 \mathrm{x}+0.41$ $(\mathrm{r}=0.85)$. There was a type $\times$ fat interaction $(P<0.01)$ indicating that the trend lines were different from one another.
$\mathrm{mL}$ in organic milks with increasing amounts of fat, respectively. An interaction between milk type and milk fat percentage was detected, with $\mathrm{E}_{2}$ concentrations increasing $(P<0.01)$ at a faster rate in the organic samples relative to the conventional samples as milk fat percentage increased. Although this interaction is not a classical one in which the regression coefficient slopes are opposite in sign, it is significant because of greater concentrations of $\mathrm{E}_{2}$ per unit of increased fat percentage (interaction of magnitude) in the organic than the conventional milk.

Estrone and $17 \beta$-estradiol were also quantified in half-and-half $(\mathrm{n}=9)$, cream $(\mathrm{n}=6)$, and butter $(\mathrm{n}$ $=12$ ) (Table 1 ). When half-and-half and cream were included in linear regression plots comparing milk fat to $\mathrm{E}_{1}$ or $\mathrm{E}_{2}$ concentrations (as in Figure 2 and Figure $3)$, least-squares equations were $\mathrm{y}=1.56 \mathrm{x}+2.79(\mathrm{r}$ $=0.99)$ and $\mathrm{y}=0.16 \mathrm{x}+0.47(\mathrm{r}=0.97)$, respectively, where y represents $\mathrm{E}_{1}$ or $\mathrm{E}_{2}$ concentration, respectively, and $\mathrm{x}$ represents milk fat percentage.

The average amount of $\mathrm{E}_{1}$ and $\mathrm{E}_{2}$ contained in 1 serving of each of the dairy products indicated that 1 serving of half-and-half ( $30 \mathrm{~mL}$ or $1.0 \mathrm{fl}$. oz) provided the least amount of $\mathrm{E}_{1}$ and $\mathrm{E}_{2}$ /serving, whereas whole milk ( $237 \mathrm{~mL}$ or $8 \mathrm{fl}$. oz) provided the greatest quantity of $\mathrm{E}_{1}$ and $\mathrm{E}_{2} /$ serving (Table 1 ).

\section{DISCUSSION}

Estrone and $17 \beta$-estradiol were consistently detected in the present study, with concentrations of $\mathrm{E}_{1}$ being 7.7 times greater than the more biologically active $\mathrm{E}_{2}$; however, concentrations of $\mathrm{E}_{1}$ and $\mathrm{E}_{2}$ in milk and other dairy products were very small (parts per trillion). Pasteurization-homogenization treatment did not significantly affect $\mathrm{E}_{2}$ concentrations in milk. To the authors' knowledge, this is the first report in which the same raw milk was analyzed for $\mathrm{E}_{2}$ before and after $\mathrm{P}-\mathrm{H}$. Others (Wolford and Argoudelis, 1979; Malekinejad et al., 2006) reported $\mathrm{E}_{1}, \mathrm{E}_{2}$, and estriol concentrations in raw and processed milk samples; however, these authors did not analyze the same milk pre- and post$\mathrm{P}-\mathrm{H}$ treatment. The P-H milk samples formed emulsions more often when ethyl acetate alone was used as a solvent for extraction. Formation of these emulsions was likely related to a change in fat globule surface chemistry caused by $\mathrm{P}-\mathrm{H}$, because emulsions did not form with raw milk samples. A mixture of ethyl acetate and hexanes $(1: 1, \mathrm{vol} / \mathrm{vol})$ reduced emulsion formation in commercial milk samples and allowed for improved extraction efficiencies.

Estrone and 17ß-estradiol concentrations were quantified from 71 unique milk samples. The number of samples analyzed in this study exceeds that of other 
Table 1. Mean concentrations ${ }^{1}$ and masses $^{2}$ of estrone $\left(\mathrm{E}_{1}\right)$ and $17 \beta$-estradiol $\left(\mathrm{E}_{2}\right)$ in dairy products with varying amounts of milk fat

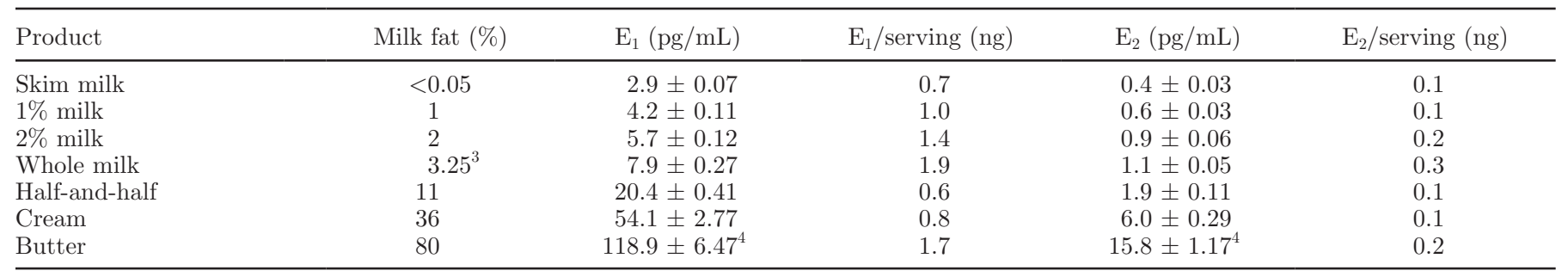

${ }^{1}$ Mean \pm standard error of the mean.

${ }^{2}$ Serving sizes were as follows: $237 \mathrm{~mL}$ ( 8 fl. oz.) for milk; $30 \mathrm{~mL}$ (1 fl. oz.) for half-and-half; $15 \mathrm{~mL}$ (0.5 fl. oz.) for cream; and $14 \mathrm{~g}$ ( $\left.1 \mathrm{tablespoon}\right)$ for butter.

${ }^{3}$ Milk fat percentage is minimally $3.25 \%$.

${ }^{4} \mathrm{E}_{1}$ and $\mathrm{E}_{2}$ concentrations for butter are in picograms per gram.

published studies and provides information on the hormone content of conventional and organic milks with differing fat contents. The concentration of both $\mathrm{E}_{1}$ and $\mathrm{E}_{2}$ increased (Figures 2 and 3 ) as the milk fat percentage increased. An increase in $\mathrm{E}_{1}$ and $\mathrm{E}_{2}$ concentrations in higher fat products including half-and-half, cream, and butter also was noted (Table 1). Garcia-Peláez et al. (2004) reported decreased $\mathrm{E}_{1}$ concentrations in milk samples with increased milk fat percentage and less $\mathrm{E}_{1}$ in butter compared with skim milk. The increase in $\mathrm{E}_{1}$ and $\mathrm{E}_{2}$ concentrations with increasing milk fat percentages observed in the current study was not surprising given the lipophilic nature of $\mathrm{E}_{1}$ and $\mathrm{E}_{2}$. Others have also reported increased $E_{1}$ and $E_{2}$ concentrations with greater percentages of milk fat (Wolford and Argoudelis, 1979; Hartmann et al., 1998; Malekinejad et al., 2006).

A small but statistically significant difference in mean concentrations of $\mathrm{E}_{2}$ in conventional versus organic milks was observed in the current study with increased concentrations of $\mathrm{E}_{2}$ at increased milk fat percentages for the organic milks. Although the 2 types were statistically different, it is unlikely that any biological significance exists in the difference in $\mathrm{E}_{2}$ between conventional and organic milks because the concentrations are so small. If the milk fat percentages in the milk were slightly more than what was reported on the label, this could contribute to the differences in observed $\mathrm{E}_{2}$ concentrations.

The milk $\mathrm{E}_{1}$ and $\mathrm{E}_{2}$ concentrations in the current report are lower than those reported in some reports (Wolford and Argoudelis, 1979; Hartmann et al., 1998; Garcia-Peláez et al., 2004; Malekinejad et al., 2006), but are similar to others (Glencross et al., 1973; Glencross and Abeywardene, 1983). Others (Hartmann et al., 1998) used organic solvent extractions, liquid column chromatography purification, and GC-MS for quantification of steroid analytes. The limit of detection was 20 to $30 \mathrm{pg} / \mathrm{g}$ depending on the product (Hartmann et al., 1998). The limit of quantification in the current report was $0.13 \mathrm{pg} / \mathrm{mL}$ because of the original milk sample volume extracted and the sensitivity of the RIA kits used for analyses. This limit of quantification may be one reason the milk $\mathrm{E}_{1}$ and $\mathrm{E}_{2}$ concentrations were lower than those reported by Hartmann et al. (1998). A separate group analyzed samples using organic solvent extractions, a $\mathrm{C}_{18}$ solid-phase extraction column, derivatization, and then liquid chromatography tandem mass spectrometry (LC-MS/MS) for quantification of estrogens (Malekinejad et al., 2006). These authors, however, pooled all samples before analysis, thus losing information about sample-to-sample variation. Others (Wolford and Argoudelis, 1979; Garcia-Peláez et al., 2004) reported average $E_{1}$ contents in whole milk of 33.7 and $1,400 \mathrm{pg} / \mathrm{mL}$, respectively, compared with $7.9 \mathrm{pg} /$ $\mathrm{mL}$ for whole milk in the present study. The extraction procedure used by Garcia-Peláez et al. (2004) was quite different from methods used in the current study or that of Wolford and Argoudelis (1979). Garcia-Peláez et al. (2004) reported greater $\mathrm{E}_{1}$ concentrations in skim milk compared with butter, which is surprising given the lipophilic nature of $E_{1}$. Different antibodies used for RIA quantifications as well as methodological differences may have contributed to the differences in concentrations observed in the present study relative to others (Wolford and Argoudelis, 1979; Garcia-Peláez et al., 2004). Raw milk samples from 206 Holstein cows were analyzed with a reported range of concentrations from nondetectable to $22.9 \mathrm{pg}$ of $\mathrm{E}_{2} / \mathrm{mL}$, with an average of $1.4 \mathrm{pg} / \mathrm{mL}$ (Pape-Zambito et al., 2007), consistent with results from the current study. A specific issue regarding differences in reported $\mathrm{E}_{2}$ concentrations may be related to the cross-reactivity of the $\mathrm{E}_{2}$ antibody with other estrogens. The $\mathrm{E}_{2}$ antibody used in the present study cross-reacted $0.68 \%$ with $17 \alpha$-estradiol, whereas previous reports have noted a 17 to $32 \%$ cross-reactivity of the $\mathrm{E}_{2}$ antibody with $17 \alpha$-estradiol (Monk et al., 1975; Eley et al., 1981). Antibodies used to detect $\mathrm{E}_{2}$ 
that significantly cross-react with $17 \alpha$-estradiol would yield artificially high predictions of $\mathrm{E}_{2}$. Methodologies that do not use antibody-based detection systems, such as HPLC, GC/MS, and LC-MS/MS may not be as prone to differences in reported concentrations across the literature as is observed for different RIA antibodies. Unfortunately, some of these chemical methods require more extensive sample manipulation, which offers potential for artifacts. Furthermore, if the sensitivity of these methods is poor, then samples that are below detection limits do not contribute to average values, so reported means can be greater than a representative set of samples. In addition, the cost of instruments can be prohibitive. Although advantages exist for using GC/ MS and LC-MS/MS for quantification purposes, the sensitivity of these instruments has only recently begun to parallel that of RIA.

Estrone and $17 \beta$-estradiol contents in butter in the present study (118.9 pg of $\mathrm{E}_{1} / \mathrm{g}$ and $15.8 \mathrm{pg}$ of $\mathrm{E}_{2} / \mathrm{g}$ ) were lesser than in other reports: $540 \mathrm{pg}$ of $\mathrm{E}_{1} / \mathrm{g}$ and 82 $\mathrm{pg}$ of $\mathrm{E}_{2} / \mathrm{g}$ (Wolford and Argoudelis, 1979), 1,470 pg of $\mathrm{E}_{1} / \mathrm{g}$ and $<30 \mathrm{pg}$ of $\mathrm{E}_{2} / \mathrm{g}$ (Hartmann et al., 1998), and $1,210 \mathrm{pg}$ of $\mathrm{E}_{1} / \mathrm{g}$ (Garcia-Peláez et al., 2004). These differences, again, may be because of analytical differences among the studies, as discussed previously.

The concentrations of $E_{1}$ and $E_{2}$ in all dairy products analyzed in the current investigation were extremely small compared with endogenous production rates in humans. Depending on the stage of the menstrual cycle, premenopausal women can produce between 50,000 to $350,000 \mathrm{ng}$ of $\mathrm{E}_{1}$ and 36,000 to $380,000 \mathrm{ng}$ of $\mathrm{E}_{2}$ per day (Ganong, 2001). One serving (237 mL, 8 fl. oz.) of $2 \%$ milk contained $1.4 \mathrm{ng}$ of $\mathrm{E}_{1}$ and 0.22 ng of $\mathrm{E}_{2}$ (Table 1). Therefore, premenopausal women produce at least 35,000 times as much $\mathrm{E}_{1}$ and 163,000 times as much $\mathrm{E}_{2}$ daily as what would be consumed in 1 serving of $2 \%$ milk. Whole milk analyzed in the present study provided the greatest quantities of $\mathrm{E}_{1}$ and $\mathrm{E}_{2}$ per serving; however, premenopausal women still produce $>8,700$ and 40,000 times more $\mathrm{E}_{1}$ and $\mathrm{E}_{2} / \mathrm{d}$, respectively, than the amount contained in 3 servings of whole milk. Postmenopausal women produce 45,000 $\mathrm{ng}$ of $\mathrm{E}_{1}$ and 12,000 $\mathrm{ng}$ of $\mathrm{E}_{2}$ daily (Anderson, 1993), so the amounts of $\mathrm{E}_{1}$ and $\mathrm{E}_{2}$ in dairy products are still small relative to endogenous production rates in postmenopausal females.

Another argument against dairy product $\mathrm{E}_{1}$ and $\mathrm{E}_{2}$ having a significant effect on human physiology is that orally ingested steroids are extensively metabolized by the gut mucosa and liver and thus have low bioavailability (Ruoff and Dziuk, 1994; O'Connell, 1995). Kuhnz et al. (1993) reported that premenopausal women given a 4-mg oral dose of $\mathrm{E}_{2}$ had peak plasma $\mathrm{E}_{2}$ concentrations of $163 \mathrm{pg} / \mathrm{mL}$ after $6.5 \mathrm{~h}$, similar to other reports in the literature (Grow, 2002; Kuhl, 2005). If it is assumed that an adult woman's blood volume is $5 \mathrm{~L}$, with a plasma volume of $3.6 \mathrm{~L}$, a mass of $0.587 \mu \mathrm{g}$ of the orally ingested $\mathrm{E}_{2}$ would be present in plasma $6.5 \mathrm{~h}$ after ingestion $(163 \mathrm{pg} / \mathrm{mL} \times 3,600 \mathrm{~mL} / 1,000,000$ for conversion to $\mu \mathrm{g}$ ). That means that only $0.01 \%$ of the total dose of $\mathrm{E}_{2}$ is present in the plasma when peak $\mathrm{E}_{2}$ concentrations are attained. If one were to consume one 8 -oz. glass of $2 \%$ milk, one serving of butter, and one serving of half-and-half with a meal, a total of 0.5 ng (or $500 \mathrm{pg}$ ) of $\mathrm{E}_{2}$ would be consumed (Table 1). If $100 \%$ was absorbed, $500 \mathrm{pg}$ would be present in 3,600 $\mathrm{mL}$ of plasma $\left(0.14 \mathrm{pg} / \mathrm{mL}\right.$ increase in $\left.\mathrm{E}_{2}\right)$. Because the theoretical increase in plasma concentrations is small compared with typical concentrations $(30 \mathrm{pg} / \mathrm{mL}$, early follicular female), it is unlikely that the amounts of $\mathrm{E}_{1}$ and $\mathrm{E}_{2}$ in dairy products cause adverse health consequences. Because others have reported that conjugated $E_{1}$ and $E_{2}$ are significantly greater than free $E_{1}$ or $E_{2}$, additional research on concentrations of estrogen conjugates in milk, as well as bioavailability, absorption rates, and metabolism of orally ingested estrogens in milk is warranted.

\section{CONCLUSIONS}

Pasteurization-homogenization did not significantly affect $\mathrm{E}_{2}$ concentrations in milk. Estrone and $17 \beta$-estradiol are present in dairy products, and the concentrations in milk are correlated with fat content. Mass of $\mathrm{E}_{1}$ in a single serving of skim, $1 \%, 2 \%$, and whole milks, half-and-half, cream, and butter averaged $0.7,1.0,1.4,1.9,0.6,0.8$, and $1.7 \mathrm{ng}$, respectively. Mass of $\mathrm{E}_{2}$ in a single serving of skim, $1 \%, 2 \%$, and whole milks, half-and-half, cream, and butter averaged 0.1, $0.1,0.2,0.3,0.1,0.1$, and $0.2 \mathrm{ng}$, respectively. Half-andhalf, cream, and butter had greater concentrations of $\mathrm{E}_{1}$ and $\mathrm{E}_{2}$ compared with milk. When all dairy products were included, no differences in $\mathrm{E}_{1}$ and $\mathrm{E}_{2}$ concentrations were detected between conventional and organic dairy products. The theoretical increases in $\mathrm{E}_{1}$ and $\mathrm{E}_{2}$ concentrations in the peripheral circulation following consumption of dairy products are minuscule relative to circulating $\mathrm{E}_{1}$ and $\mathrm{E}_{2}$ concentrations in humans.

\section{ACKNOWLEDGMENTS}

This work was supported by funds from USDA Special grant no. 2003-34163-13404 to Ronald Kensinger. The authors thank Ann Magliaro Macrina, Bradley Martin, Michael Harper, and Shannon VanDyke (all of The Pennsylvania State University) for help with sample preparation, analyses, and manuscript preparation. The authors also thank the reviewers for provid- 
ing several suggestions to improve the quality of this manuscript.

\section{REFERENCES}

Anderson, F. 1993. Kinetics and pharmacology of estrogens in preand postmenopausal women. Int. J. Fertil. Menopausal Stud. 38(Suppl. 1):55-64.

Berkey, C. S., H. R. Rockett, W. C. Willett, and G. A. Colditz. 2005. Milk, dairy fat, dietary calcium, and weight gain: a longitudinal study of adolescents. Arch. Pediatr. Adolesc. Med. 159:543-550.

Courant, F., J. P. Antignac, J. Laille, F. Monteau, F. Andre, and B. Le Bizec. 2008. Exposure assessment of prepubertal children to steroid endocrine disruptors. 2. Determination of steroid hormones in milk, egg, and meat samples. J. Agric. Food Chem. 56:31763184 .

Courant, F., J. P. Antignac, D. Maume, F. Monteau, F. Andre, and B. Le Bizec. 2007. Determination of naturally occurring oestrogens and androgens in retail samples of milk and eggs. Food Addit. Contam. 24:1358-1366.

Eley, D. S., W. W. Thatcher, H. H. Head, R. J. Collier, and C. J. Wilcox. 1981. Periparturient endocrine changes of conceptus and maternal units in Jersey cows bred for milk yield. J. Dairy Sci. 64:296-311.

Ganmaa, D., and A. Sato. 2005. The possible role of female sex hormones in milk from pregnant cows in the development of breast, ovarian and corpus uteri cancers. Med. Hypotheses 65:1028-1037.

Ganmaa, D., P. Y. Wang, L. Q. Qin, K. Hoshi, and A. Sato. 2001. Is milk responsible for male reproductive disorders? Med. Hypotheses $57: 510-514$.

Ganong, W. F. 2001. Review of Medical Physiology. 20th ed. McGrawHill, New York, NY.

Garcia-Peláez, B., R. Ferrer-Lorente, S. Gomez-Olles, J. A. FernandezLopez, X. Remesar, and M. Alemany. 2004. Technical note: Measurement of total estrone content in foods. Application to dairy products. J. Dairy Sci. 87:2331-2336.

Glencross, R. G., and S. A. Abeywardene. 1983. Concentrations of oestradiol-17 $\beta$ and progesterone in plasma and defatted milk of cattle during the oestrous cycle. Br. Vet. J. 139:49-51.

Glencross, R. G., I. B. Munro, B. E. Senior, and G. S. Pope. 1973. Concentrations of oestradiol-17 $\beta$, oestrone and progesterone in jugular venous plasma of cows during the oestrous cycle and in early pregnancy. Acta Endocrinol. (Copenh.) 73:374-384.

Grow, D. R. 2002. Metabolism of endogenous and exogenous reproductive hormones. Obstet. Gynecol. Clin. North Am. 29:425-436.

Hartmann, S., M. Lacorn, and H. Steinhart. 1998. Natural occurrence of steroid hormones in food. Food Chem. 62:7-20.

Jemal, A., R. Siegel, E. Ward, Y. Hao, J. Xu, and M. J. Thun. 2009 Cancer statistics, 2009. CA Cancer J. Clin. 59:225-249.

Kensinger, R. S., R. J. Collier, F. W. Bazer, and R. R. Kraeling. 1986. Effect of number of conceptuses on maternal hormone concentrations in the pig. J. Anim. Sci. 62:1666-1674.

Kuhl, H. 2005. Pharmacology of estrogens and progestogens: Influence of different routes of administration. Climacteric 8(Suppl. 1):363.
Kuhnz, W., C. Gansau, and M. Mahler. 1993. Pharmacokinetics of estradiol, free and total estrone, in young women following single intravenous and oral administration of $17 \beta$-estradiol. Arzneimittelforschung 43:966-973.

Li, X. M., D. Ganmaa, and A. Sato. 2003. The experience of Japan as a clue to the etiology of breast and ovarian cancers: Relationship between death from both malignancies and dietary practices. Med. Hypotheses 60:268-275.

Malekinejad, H., P. Scherpenisse, and A. A. Bergwerff. 2006. Naturally occurring estrogens in processed milk and in raw milk (from gestated cows). J. Agric. Food Chem. 54:9785-9791.

Mikhail, G., C. H. Wu, M. Ferin, and R. L. Vande Wiele. 1970 Radioimmunoassay of plasma estrone and estradiol. Steroids 15:333-352

Monk, E. L., R. E. Erb, and T. A. Mollett. 1975. Relationships between immunoreactive estrone and estradiol in milk, blood, and urine of dairy cows. J. Dairy Sci. 58:34-40.

O'Connell, M. B. 1995. Pharmacokinetic and pharmacologic variation between different estrogen products. J. Clin. Pharmacol 35(Suppl.):18S-24S.

Pape-Zambito, D. A., A. L. Magliaro, and R. S. Kensinger. 2007. Concentrations of $17 \beta$-estradiol in Holstein whole milk. J. Dairy Sci. 90:3308-3313.

Pape-Zambito, D. A., A. L. Magliaro, and R. S. Kensinger. 2008 $17 \beta$-Estradiol and estrone concentrations in plasma and milk during bovine pregnancy. J. Dairy Sci. 91:127-135

Qin, L. Q., P. Y. Wang, T. Kaneko, K. Hoshi, and A. Sato. 2004 Estrogen: One of the risk factors in milk for prostate cancer. Med. Hypotheses 62:133-142.

Ruoff, W. L., and P. J. Dziuk. 1994. Absorption and metabolism of estrogens from the stomach and duodenum of pigs. Domest. Anim. Endocrinol. 11:197-208.

Sharpe, R. M., and N. E. Skakkebaek. 1993. Are oestrogens involved in falling sperm counts and disorders of the male reproductive tract? Lancet 341:1392-1395.

Tollefsen, K. E., R. Mathisen, and J. Stenersen. 2003. Induction of vitellogenin synthesis in an Atlantic salmon (Salmo salar) hepatocyte culture: A sensitive in vitro bioassay for the oestrogenic and anti-oestrogenic activity of chemicals. Biomarkers 8:394407.

Vicini, J., T. Etherton, P. Kris-Etherton, J. Ballam, S. Denham, R. Staub, D. Goldstein, R. Cady, M. McGrath, and M. Lucy. 2008. Survey of retail milk composition as affected by label claims regarding farm-management practices. J. Am. Diet. Assoc. 108:1198-1203.

Wolford, S. T., and C. J. Argoudelis. 1979. Measurement of estrogens in cow's milk, human milk, and dairy products. J. Dairy Sci. 62:1458-1463.

Yue, W., R. J. Santen, J. P. Wang, Y. Li, M. F. Verderame, W. P. Bocchinfuso, K. S. Korach, P. Devanesan, R. Todorovic, E. G. Rogan, and E. L. Cavalieri. 2003. Genotoxic metabolites of estradiol in breast: Potential mechanism of estradiol induced carcinogenesis. J. Steroid Biochem. Mol. Biol. 86:477-486. 